\title{
ОТ РЕДАКЦИИ
}

$\mathrm{B}$ настоящий выпуск журнала «Шаги / Steps», целиком посвященный востоковедческой тематике, вошли работы специалистов, представляющих ведущие центры московского востоковедения и занимающихся проблемами изучения литературного и общекультурного наследия классических цивилизаций Ближнего и Дальнего Востока (Институт восточных культур и античности РГГУ, Лаборатория востоковедения и сравнительно-исторического языкознания ШАГИ РАНХИГС, Институт классического Востока и античности НИУ ВШЭ). Несмотря на то что в качестве объектов исследования в этих работах выбраны памятники, мало или совсем не знакомые отечественному читателю, мы надеемся, что представленные в них элементы филологического анализа и культурологического комментария могут быть интересны не только для узких специалистов-востоковедов, но и вообще для всех, кто так или иначе интересуется общим вкладом восточной литературной, религиозной и исторической мысли в культурный фонд планеты.

Ключевой проблемой современного востоковедения продолжает оставаться задача и нтерпретаци и классических текстов - как в самом прямом смысле («интерпретация» как пе ре в о смыслов на другой язык, в нашем случае на русский), так и в плане раскрытия глубинных смыслов, скрывающихся за художественной образностью или перифразированием, а иногда и просто труднопостижимых за счет неадекватного понимания особенностей классических языков, отделенных от нашего времени периодами в одну-две тысячи лет. Большинство работ, представленных в данном номере журнала, объединены этой общей тематикой, формально распадаясь на две категории: 1) работы в жанре «перевод — комментарий», представляющие вниманию читателя оригинальный опыт перевода классических текстов в сопровождении филологического и культурологического комментария, и 2) чисто исследовательские работы, фокусирующиеся на определенных смыслах, семантических полях и концептах, которые сложились в рамках той или иной восточной культуры, и анализирующие их выражение и историческую эволюцию на материале целого исторического среза культурной традиции.

К первой группе работ, собранной в разделе «Переводы и комментарии», относится коллективное исследование (А. Б. Старостина и др.) первого раздела трактата Лу Цзя «Новые речи», имеющего ключевое значение для складывания классической «имперской» традиции Китая. Специально для этого исследования авторы разработали особую структуру комментария, включающую два уровня: «лингвофилологический», раскрывающий специфику построения древнекитайского текста, и (более традиционный) «общекультурный». Менее амбициозен по замыслу, но небезынтересен для всех, интересующихся фольклорной и мифологической традицией Китая, выполненный А. Б. Старостиной комментарий к переводу одной из частей крупнейшего памятника средневековой китайской словесности «Тайпин гуан цзи», в которой собраны разнообразные предания и легенды о необычных и чудесных камнях. Религиозная тематика представлена в разделе переводом и комментарием М. А. Алонцева к «Поминанию Джа“фара Садика» - главе одного из наиболее значительных суфийских памятников классического Ирана, «Поминания друзей Божиих» Фарид ад-Дина 'Аттара. 
Раздел «Статьи», посвященный непосредственно аналитическим исследованиям, тематически расходится на «ближневосточный» (Иран и исламская цивилизация в целом) и «дальневосточный» (Япония) блоки. В «ближневосточном» блоке внимание как востоковедов, так и специалистов в области философии, филологии и истории науки должна привлечь статья Н. Ю. Чалисовой, раскрывающая специфические художественно-литературные особенности классических персидских ученых трактатов, по западным меркам обычно причисляемых к разряду «не-литературы». Статьи Е. Л. Никитенко и Л. Г. Лахути посвящены, соответственно, интерпретации понятия «достоинство» в культуре персоязычного мира XV-XVIII вв. и метафорическому потенциалу понятия «море» в поэмах упомянутого выше Фарид ад-Дина 'Аттара. В «дальневосточном» блоке к этим работам тематически примыкает исследование Н. Н. Трубниковой, посвященное эволюции буддийской образности в средневековом японском памятнике «Собрание песка и камней».

Особняком в этом ряду стоят две статьи, связанные с отношениями между Востоком и Россией, точнее - с восприятием отдельных элементов восточной культуры в те или иные периоды российской истории. Так, в работе А. Н. Мещерякова исследуется специфика переводов и анализа классической японской литературы в раннем и позднем СССР, в то время как О. Ю. Бессмертная обращается к самому началу XX в., анализируя расхожие для этого времени представления об исламской культуре в рамках концепции «панисламизма», которую она рассматривает как одно из частных проявлений ориентализма - способов изобретения и описания Востока как Другого в Новое время. И та и другая статьи должны, на наш взгляд, особенно заинтересовать отечественного читателя, поскольку представленные в них выводы не в меньшей степени важны для понимания традиционного российского менталитета, чем для расширения представлений о классической японской или исламской цивилизациях. 